\title{
A closure study of cloud condensation nuclei in the North China Plain using droplet kinetic condensational growth model
}

\author{
F. Yang, H. Xue, Z. Deng, C. Zhao, and Q. Zhang \\ Department of Atmospheric and Oceanic Sciences, School of Physics, Peking University, Beijing, China
}

Correspondence to: H. Xue (hxue@pku.edu.cn)

Received: 11 September 2011 - Published in Atmos. Chem. Phys. Discuss.: 26 October 2011

Revised: 22 May 2012 - Accepted: 23 May 2012 - Published: 22 June 2012

\begin{abstract}
Aerosol size distribution and cloud condensation nucleus $(\mathrm{CCN})$ number concentration were measured in the North China Plain from 31 December 2009 to 20 January 2010. The CCN closure study was performed using these data and droplet kinetic condensational growth model. The calculated CCN concentration with the assumption of pure ammonium sulfate aerosol is $40-140 \%$ higher than that observed for the supersaturations in this study. A sensitivity test on aerosol solubility and mixing state indicates that $0.2-$ 0.5 mass fraction of ammonium sulfate for internal mixture can lead to a ratio of $0.82-1.30$ for the calculated to observed $\mathrm{CCN}$ concentrations, and that $0.4-0.7$ mass fraction of ammonium sulfate for external mixture results in a ratio of 0.74 1.25 in the North China Plain during the time period of the field observations, suggesting that a relatively simple scheme may be used for CCN prediction in climate models for this region. Finally, we compare the calculated CCN concentrations from the kinetic condensational growth model and the equilibrium model. The kinetic condensational growth model can simulate droplet growth in a time period under a certain supersaturation, while the equilibrium model only predicts whether a certain aerosol can be activated as $\mathrm{CCN}$ under that supersaturation. The $\mathrm{CCN}$ concentration calculated with the kinetic model is higher than that with the equilibrium model at supersaturations of $0.056 \%$ and $0.083 \%$, because some particles that are not activated from the equilibrium pointof-view can grow large enough to be considered as $\mathrm{CCN}$ in the kinetic model. While at a supersaturation of $0.17 \%, \mathrm{CCN}$ concentration calculated with the kinetic model is lower than that with the equilibrium model, due to the limitation of droplet kinetic growth. The calculated CCN concentrations using the kinetic model and the equilibrium model are the same at supersaturations of $0.35 \%$ and $0.70 \%$.
\end{abstract}

\section{Introduction}

Aerosols play an important role in cloud physics, climate and hydrological cycle. Previous studies have shown that the increase of aerosol number concentration, due to either natural or anthropogenic sources, can increase CCN concentration and enhance cloud albedo (Twomey, 1977). In addition, more aerosols that lead to higher CCN concentration and smaller cloud droplets for fixed liquid water, can suppress precipitation and, thus, extend the cloud lifetime and increase fractional cloudiness (Albrecht, 1989). However, the aerosol-cloud interaction is very complex and uncertain (IPCC, 2007; Lohmann and Feichter, 2005) because aerosol size distributions, chemical compositions, mixing states and meteorological parameters can all affect the properties of the clouds (Ackerman et al., 2000; Nenes et al., 2002; Peng and Lohmann, 2003; Rotstayn and Liu, 2003).

Many investigations have been carried out to study the aerosol effects on clouds and climate (e.g., Ackerman et al., 2004; Anderson et al., 2003; Boucher and Lohmann, 1995; Feingold et al., 2003; Lohmann and Feichter, 1997; Penner et al., 2004; Xue and Feingold, 2006). Studies showed that cloud droplets were smaller in polluted clouds than those in clean clouds over the Atlantic Ocean (Brenguier et al., 2000; Schwartz et al., 2002). Ship tracks are famous evidences of the Twomey effect (Ferek et al., 1998). Some observations of ship tracks (Ferek et al., 2000) and boundary layer clouds (Heymsfield and MacFarquhar, 2001; Hudson and Yum, 2001) confirm that precipitation can be suppressed by aerosols. In addition, satellite data revealed plumes of reduced cloud particle size and suppressed precipitation originating from some major urban areas and industrial facilities such as power plants (Rosenfeld, 2000). 
A major challenge of understanding the aerosol effects on clouds and climate is to know the ability of aerosol particles acting as $\mathrm{CCN}$ at a specific ambient supersaturation. Satellites, networks of ground-based instruments and dedicated field experiments are used to continuously observe the aerosol distribution and composition at different regions (Bates et al., 1998; Delene and Ogren, 2002; Kaufman et al., 2002; Ramanathan et al., 2001). Studies show that different compositions of aerosol particles have different chemical properties, resulting in different $\mathrm{CCN}$ activation (Bilde and Svenningsson, 2004; McFiggans et al., 2005). Laboratory studies show that the activation of pure black carbon particles requires higher supersaturations than that predicted by calculations where the particles are represented as insoluble and wettable spheres, and that the addition of a small amount of $\mathrm{NaCl}$ to the black carbon particles greatly enhanced their CCN efficiency (Dusek et al., 2006). In addition to the chemical composition of aerosol, the size distribution, the mixing state and a detailed knowledge of how different compounds interact with water, are required to accurately predict how a realistic aerosol population will undergo cloud nucleation (Andreae and Rosenfeld, 2008; McFiggans et al, 2006; Ward et al., 2010). Two different types of mixture, internal mixture and external mixture, are often observed in field measurements (Väkevä et al., 2002; Schwarz et al., 2006) and used in model studies (Textor et al., 2006; Wang et al., 2010). For example, field measurements by Väkevä et al. (2002) showed that externally mixed aerosol was sometimes observed at urban and forest sites in Finland and a coastal site in western Ireland. Schwarz et al. (2006) presented results that the number fraction of internally mixed black carbon particles range from 0.2 to 0.8 .

Closure studies of $\mathrm{CCN}$ have been carried out for more than $20 \mathrm{yr}$ based on both aircraft and ground-based measurements. The earlier attempts to achieve CCN closure include studies by Bigg (1986) and Quinn et al. (1993). Bigg (1986) predicted CCN concentrations 3-5 times higher than the observed CCN concentrations under polluted aerosol conditions, while the $\mathrm{CCN}$ concentration predicted by Quinn et al. (1993) based on an ammonium sulfate assumption was a factor of 2 higher than the measured $\mathrm{CCN}$ concentrations at $0.3 \%$ supersaturation. VanReken et al. (2003) predicted CCN concentration using classical Köhler theory (Köhler, 1936) assuming an idealised composition of pure ammonium sulfate for the aerosols. Their analysis indicates that there was generally good agreement between the predicted and observed CCN concentrations: at a supersaturation of $0.2 \%$, the predicted $\mathrm{CCN}$ is $5 \%$ higher than that observed; while at a supersaturation of $0.85 \%$, the predicted $\mathrm{CCN}$ is $20 \%$ higher. As the compositions of the aerosols in the environment are very complex (Kanakidou et al., 2005; Murphy et al., 2006; Zhang et al., 2007), Köhler theory has been extended to include organic species or insoluble matters (Facchini et al., 1999; Kulmala et al., 1997; Laaksonen et al., 1998; Seinfeld and Pandis, 1998; Shulman et al., 1996), and has been proved successful by laboratory studies (Bilde and Svenningsson, 2004; Henning et al., 2005; Raymond and Pandis, 2002, 2003; Svenningsson et al., 2006). Another method derived from Köhler theory is called " $\kappa$-Köhler theory", which employs a single parameter $\kappa$ to describe the solubility effect on CCN activation (Petters and Kreidenweis, 2007). Conant et al. (2004) indicated that the lack of aerosol-CCN closure brings into question either (1) our fundamental understanding of the role of aerosol composition on the CCN spectrum or (2) the techniques used to determine $\mathrm{CCN}$ spectrum or composition and mixing state. Therefore, in order to improve the aerosol-CCN closure, chemical properties of aerosols have been widely studied. Although the two questions above have not been completely solved, the roles of chemical properties including solubility, surface tension and oxidation state in $\mathrm{CCN}$ activation are now better understood (Bougiatioti et al., 2009; Broekhuizen et al., 2004, 2006; Cantrell et al., 2001; Ervens, 2007; Jurányi et al., 2010; Wang et al., 2010).

Classical Köhler theory predicts the critical supersaturation of a particle and, thus, does not incorporate any potential kinetic limitations to cloud droplet formation (Ruehl et al., 2008). Chuang et al. (1997) showed that neglecting kinetic limitations on the water uptake of cloud droplets can lead to overestimations in cloud radiative forcing calculations. Nenes et al. (2001) identified three mechanisms that lead to kinetic limitations for cloud droplet activation. The first mechanism that limits the formation of activated droplets is the "inertial mechanism" described by Chuang et al. (1997), where the timescale of cloud formation is not sufficient for these particles with a large dry diameter and a very low critical supersaturation to reach their critical diameter. The second mechanism is that the particle initially grows, but subsequently evapourates to stay as an interstitial aerosol particle before it can activate, which is called "evapouration mechanism". Thirdly, some particles can initially activate, but become interstitial aerosols through the so-called "deactivation mechanism". The water vapour mass accommodation coefficient also has a strong effect on the condensation rate of water and remains an outstanding uncertainty in quantifying the indirect effect of aerosols on climate forcing. Literature values of water accommodation coefficient span two orders of magnitude, from 0.01 to 1.0 (e.g., Davidovits et al., 2004; Laaksonen et al., 2005; Marek and Straub, 2001; Mozurkewich, 1986; Shaw and Lamb, 1999). Shantz et al. (2010) showed that water accommodation coefficient is about 0.04, while Voigtländer et al. (2007) indicates that it is larger than 0.30 using a flow chamber experiment. Ruehl et al. (2008) suggest that for some air masses, accurate quantification of CCN concentrations may need to account for kinetic limitations.

In this paper, we present a $\mathrm{CCN}$ closure study using data from the North China Plain and droplet kinetic condensational growth model. Section 2 will describe the observed data, while the theory of droplet condensational growth will 
be discussed in Sect. 3. Section 4 will present the results and discussion. The conclusion will be presented in Sect. 5 .

\section{Data description}

This study uses data from experiments carried out at Wuqing in the North China Plain, which is sometimes heavily polluted by anthropogenic aerosols, from 31 December 2009 to 20 January 2010. Wuqing is located between the high aerosol optical depth centres of Beijing and Tianjin, and represents a suburban background state in the North China Plain region (Xu et al., 2011). Many observations and studies have been operated in the North China Plain. For example, Wu et al. (2008) studied the particle number size distribution in the urban atmosphere of Beijing, while Liu et al. (2011) studied the hygroscopic properties of aerosols in the Wuqing region in summer. Our study focuses on the aerosol activation properties in this region in winter. No precipitation or fog occurred at Wuqing during the experiment, and the dominant wind direction was southerly which means that a high level of pollution could be transported to the site from the major source regions of eastern Tianjin. The aerosol size distribution and the $\mathrm{CCN}$ number concentration were measured during the experiment. Details of the aerosol and $\mathrm{CCN}$ instrumentations and data in our study can be found in Deng et al. (2011).

Aerosol number size distributions (radius from 7 to $375 \mathrm{~nm}$ ), which were obtained by a Scanning Mobility Particle Sizer (SMPS, Model 3936, TSI, USA) with a time resolution of five minutes, are divided into 110 bins with the same logarithmic interval. The SMPS consist mainly of Differential Mobility Analyzer (DMA, Model 3081) and Condensation Particle Counter (CPC, Model 3772). The aerosol measurement equipment in this study has an upper truncation radius of $375 \mathrm{~nm}$ and does not include larger particles. However, it should be noted that aerosol number concentration in Wuqing was about $10000-40000 \mathrm{~cm}^{-3}$ (Deng et al., 2011) during the experimental period and larger particles only occupy a small number fraction (less than $1 \%$ ) of the total aerosols because the particles are mainly from pollution in this area. This neglect of larger particles will only slightly underpredict $\mathrm{CCN}$ concentrations.

The $\mathrm{CCN}$ concentrations at a given supersaturation (nominally $0.07,0.10,0.20,0.40$ and $0.80 \%$ ) were obtained from a continuous-flow dual CCN counter (CCN-200, DMT) (Roberts and Nenes, 2005; Lance et al., 2006). The CCN counter was calibrated with ammonium sulfate particles (Rose et al., 2008), and the calibration shows that the effective supersaturations were $0.056,0.083,0.17,0.35$ and $0.70 \%$ for corresponding measurements (Deng et al., 2011). These calibrated supersaturations are used in the calculations of CCN concentration in this study. The measured particle diameter range is from 0.75 to $10 \mu \mathrm{m}$ using the $\mathrm{CCN}$ counter. However, the practical upper size for the $\mathrm{CCN}$ counter is probably much smaller than $10 \mu \mathrm{m}$ for instrumental and size distribution reasons.

\section{Model and method}

The diffusive growth rate of a droplet has the form (Pruppacher and Klett, 1997, p. 511)

$r \frac{\mathrm{d} r}{\mathrm{~d} t}=\frac{D\left(e-e_{\mathrm{r}}(T)\right)}{\frac{\rho_{\mathrm{w}} R T}{M_{\mathrm{w}}}+\frac{e_{\mathrm{s}}(T) D \rho_{\mathrm{w}} L}{T k}\left(\frac{L M_{\mathrm{w}}}{R T}-1\right)}$

where $e$ is the water vapour pressure in the ambient air, $e_{\mathrm{r}}$ the water vapour pressure over the droplet surface, $e_{\mathrm{S}}$ the equilibrium vapour pressure over a flat water surface, $r$ the radius of the droplet, $T$ the ambient air temperature, $R$ the universal gas constant, and $L$ the latent heat of water condensation; $M_{\mathrm{w}}$ and $\rho_{\mathrm{w}}$ are, respectively, the molecular weight and density of water; $D$ and $k$ are, respectively, the effective diffusion coefficient of water vapour in the air and effective thermal conductivity of air, including the gas kinetic effects. $e_{\mathrm{r}}$ can be expressed as

$e_{\mathrm{r}}=e_{\mathrm{s}} a_{\mathrm{w}} \exp \left(\frac{2 \sigma M_{\mathrm{w}}}{\rho_{\mathrm{w}} R T r}\right)$

where $a_{\mathrm{w}}$ is the water activity and $\sigma$ is the surface tension over the droplet surface. The parameterization of water activity for a solution of ammonium sulfate is represented by the polynomial expression, as below, in this paper (Tang and Munkelwitz, 1994)

$$
\begin{aligned}
a_{\mathrm{w}} & =1.0-2.715 \times 10^{-3} x+3.113 \times 10^{-5} x^{2} \\
& -2.336 \times 10^{-6} x^{3}+1.412 \times 10^{-8} x^{4}
\end{aligned}
$$

where $x$ is the mass fraction of ammonium sulfate in the solution.

The composition of aerosol particles was first assumed to be pure ammonium sulfate. The reasons are that: (1) ammonium sulfate is the main chemical material in the aerosols in urban area (Wang et al., 2006); (2) the chemical properties of ammonium sulfate are well understood, especially the water activity (Tang and Munkelwitz, 1994); (3) a previous study in Wuqing found that the growth properties of the more hygroscopic particles are close to pure ammonium sulfate, indicating that these particles contain large fractions of inorganic compounds (Liu et al., 2011). The same assumption can be found in previous studies (Dusek et al., 2003).

In the $\mathrm{CCN}$ closure in this study, we also assume that the aerosols consist of ammonium sulfate and insoluble materials. We change the mass fraction of ammonium sulfate in the aerosols to test the effect of aerosol solubility on $\mathrm{CCN}$ closure. Both internally and externally mixed aerosols are investigated. The internal mixture state is represented as an insoluble kernel with an ammonium sulfate shell, and the external mixture state is pure ammonium sulfate aerosol externally mixed with the insoluble material. 
Both the kinetic condensational growth model (Eq. 1) and the equilibrium model (Eq. 2) are used to predict CCN number concentrations at a given supersaturation. The observed 110 bins of aerosols are used as inputs to both models. The equilibrium model can predict the critical supersaturation of the particle with a given dry radius. Particles with the critical supersaturation smaller than the ambient supersaturation can be considered as CCN. However, the equilibrium method has a defect: particles may not have enough time to grow to their critical sizes. It has been shown that particles sometimes are not in equilibrium with the environment and the kinetic effect leads to limitations of droplet activation in clouds (Nenes et al., 2001). This kinetic limitation effect may also exist in $\mathrm{CCN}$ counters. In this study, a kinetic condensational growth model is used to simulate particle growth in the $\mathrm{CCN}$ counter. We first calculate the initial equilibrium radius of each bin at the measured temperature, pressure and at a relative humidity of $85 \%$ using Eq. (2). Then we calculate the growth of the droplets with time at the measured supersaturations using the condensational growth model (Eq. 1). The water accommodation coefficient for this study is taken to be 0.04 on the basis of the laboratory studies of Shaw and Lamb (1999). We also did a sensitivity test on the effect of water accommodation coefficient on droplet growth rate using values of 0.3 and 1.0.

Based on the setup of the CCN counter (Deng et al., 2011), we consider that the time for particles to stay in the counter (resident time) is roughly $10 \mathrm{~s}$. Because the $\mathrm{CCN}$ instrument can measure droplet size from 0.75 to $10 \mu \mathrm{m}$ in diameter, we consider particles that grow larger than $1.0 \mu \mathrm{m}$ after the resident time as $\mathrm{CCN}$ in the kinetic model calculation, although some of them may not be "activated" in the classical equilibrium method. The calculated CCN number concentration using the kinetic condensational growth model is then compared with that from the equilibrium model. Details of the comparison can be found in Sect. 4.3.

\section{Results and discussion}

\subsection{CCN Closure using droplet kinetic condensational growth model}

Figure 1 shows the comparison of calculated and observed $\mathrm{CCN}$ number concentrations during the experiment time at different supersaturations. The calculated $\mathrm{CCN}$ number concentration is obtained from the kinetic condensational growth model, as discussed in Sect. 3. Aerosols are first assumed as pure ammonium sulfate and the water accommodation coefficient is 0.04 . The averages and standard deviations of the calculated and measured CCN concentrations for each supersaturation are also shown in Fig. 1. It can be noted that the calculated CCN concentration is 140,100, 40, 40 and $50 \%$ higher than the observed $\mathrm{CCN}$ concentration on average at supersaturations of $0.056,0.083,0.17,0.35$ and $0.70 \%$, respectively.

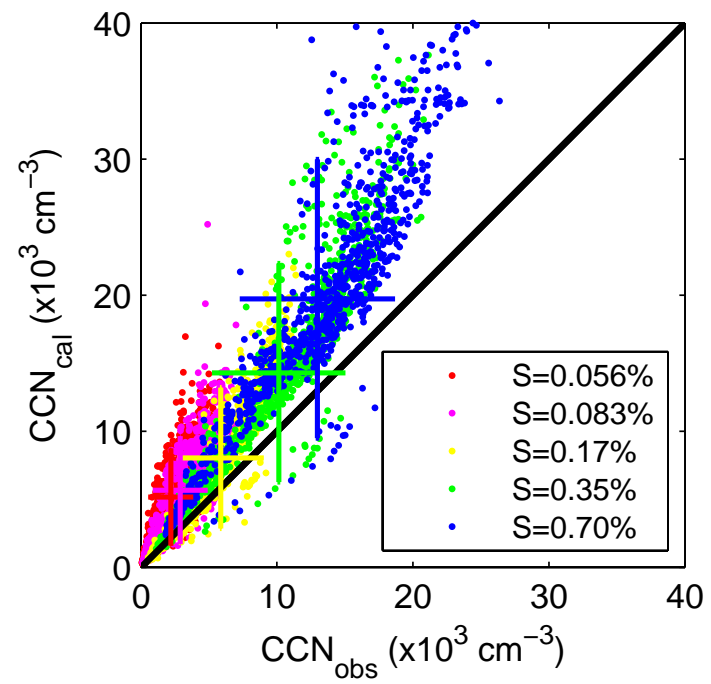

Fig. 1. Comparison between the calculated and observed CCN number concentration during 31 December 2009 and 20 January 2010 at Wuqing. The composition of aerosol is assumed to be pure ammonium sulfate and the water accommodation coefficient is 0.04. Different colours represent different supersaturations (red: $S=0.056 \%$; pink: $S=0.083 \%$; yellow: $S=0.17 \%$; green: $S=$ $0.35 \%$; blue: $S=0.70 \%$ ). The centre of the cross represents the mean calculated $\mathrm{CCN}$ concentration and the mean observed $\mathrm{CCN}$ concentration at each supersaturation. Horizontal and vertical bars indicate the standard deviations of the observed CCN and calculated $\mathrm{CCN}$ concentrations, respectively.

The possible reasons for the overestimation of $\mathrm{CCN}$ concentration using the kinetic model include: (1) aerosols are assumed to be pure ammonium sulfate in the model, while the ambient aerosols may contain some insoluble material; (2) the high concentration of aerosol particles lead to consumption of water vapour and a lower supersaturation than expected in the CCN counter. In fact, there is some evidence that the actual supersaturation in the $\mathrm{CCN}$ counter is lower than the expected value, especially at higher CCN concentration (Lathem and Nenes, 2011).

\subsection{Sensitivity to aerosol solubility and mixing state}

Previous studies showed that the amount of the soluble matters (Petters and Kreidenweis, 2008; Koch et al., 2011; Khvorostyanov and Curry, 2007), slightly soluble organics (Bilde and Svenningssoon, 2004), and the surface active compounds (Facchini et al., 1999; Henning et al., 2005) can all influence the aerosol activation behaviour. It has been demonstrated that the calculated $\mathrm{CCN}$ concentration was highly sensitive to the assumed aerosol mixing state and that the lack of mixing state measurements precludes a quantitative evaluation of its effect on CCN closure (Stroud et al., 2007). Ervens et al. (2010) studied the impact of the assumed aerosol mixing state and composition on calculated $\mathrm{CCN}$ concentration and found that for an aerosol with small 


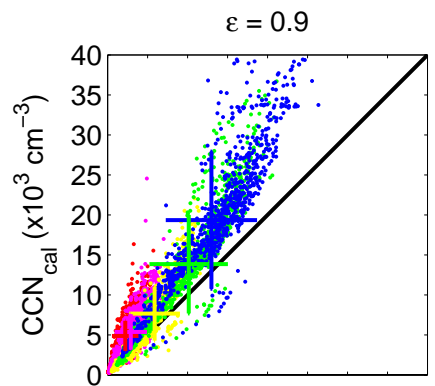

$\varepsilon=0.5$

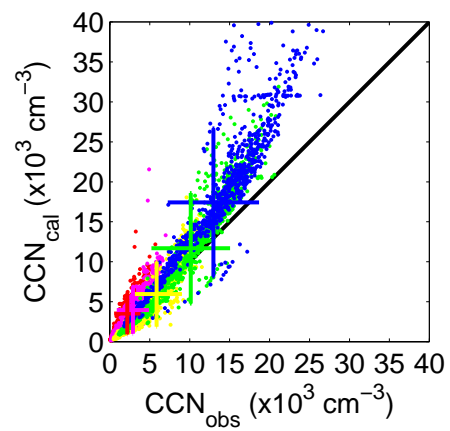

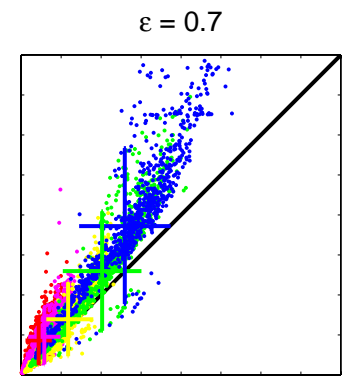

$\varepsilon=0.3$

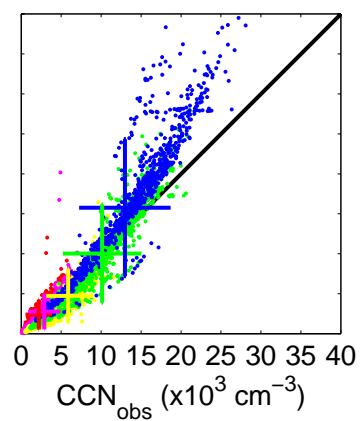

Fig. 2. Comparison between the calculated and observed CCN number concentration for four different mass fractions of ammonium sulfate $(\varepsilon)$ at different supersaturations. For each aerosol, ammonium sulfate is assumed to be internally mixed with an insoluble core. Colour coding of supersaturations and the representation of mean and standard deviation is as in Fig. 1.

organic mass fraction, the assumption of organic composition/mixing state is not crucial, while for high organic mass fraction, predicted $\mathrm{CCN}$ number concentrations are quite sensitive to the assumptions on mixing state/composition.

To investigate the sensitivity of closure results to aerosol solubility and mixing state, we first assume that aerosol is composed of internally-mixed ammonium sulfate and insoluble material. We vary the mass fraction of ammonium sulfate $(\varepsilon)$ in the model from 0.9 to 0.3 . When aerosols absorb water from the environment during the hygroscopic growth, each droplet is assumed to have an insoluble core and a shell of ammonium sulfate solution. The equilibrium vapour pressure over the droplet is then the equilibrium vapour pressure over ammonium sulfate solution with the curvature effect. This can be derived from Eqs. (2) and (3). We then use Eq. (1) to calculate the kinetic growth of the droplets. Droplet size is determined from the size of the insoluble core and the amount of the ammonium sulfate solution.

Figure 2 shows the comparison of the calculated and observed CCN number concentrations at different supersaturations for mass fraction of ammonium sulfate from 0.9 to 0.3 . It can be seen that the calculated $\mathrm{CCN}$ concentration is decreasing with the decrease of ammonium sulfate mass fraction. The ratio of the calculated to the measured $\mathrm{CCN}$ concentration for different mass fraction of ammonium sulfate (from 1.0 to 0.1 ) and five supersaturations is shown in
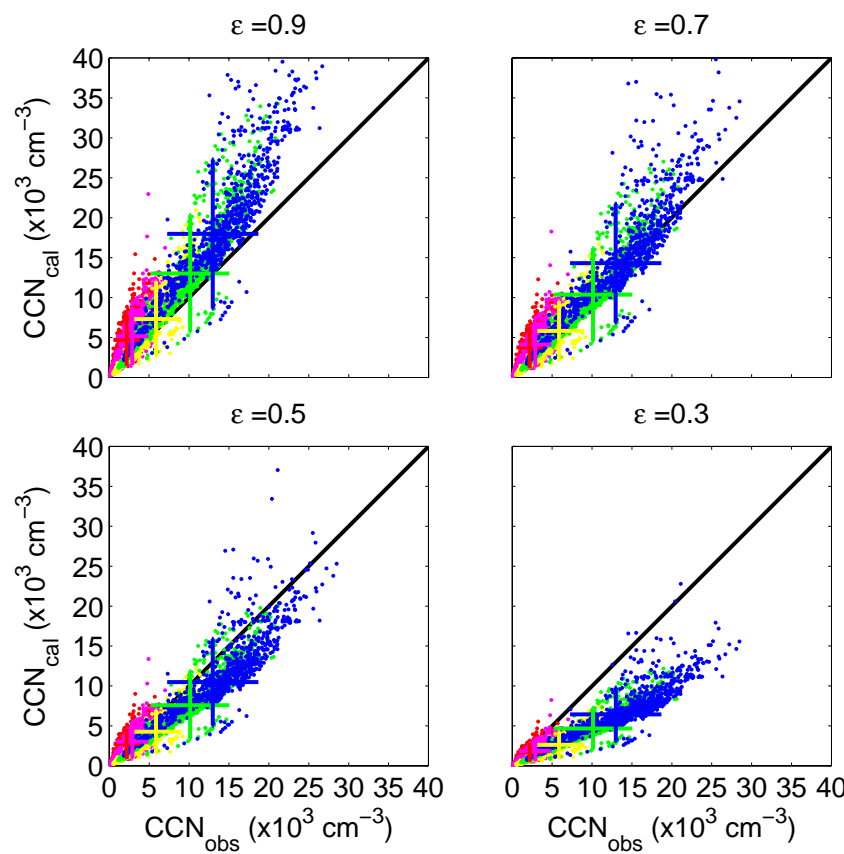

Fig. 3. Comparison between the calculated and observed CCN number concentration for 4 different mass fractions of ammonium sulfate $(\varepsilon)$ at different supersaturations. The insoluble material is assumed to be externally mixed with ammonium sulfate. Colour coding of supersaturations and representation of mean and standard deviation is as in Fig. 1.

Table 1a. The best-fit mass fraction of ammonium sulfate is $0.3,0.3,0.5,0.3$ and 0.2 at supersaturations of $0.056 \%$, $0.083 \%, 0.17 \%, 0.35 \%$ and $0.70 \%$, respectively.

Secondly, we assume that ammonium sulfate is externally mixed with insoluble material. Externally mixed aerosols were observed at many places (e.g., Väkevä et al., 2002) and have been assumed in many regional scale models (Koch et al., 1999; Chin et al., 2000; Boucher and Anderson, 1995; Barth et al., 2000). The insoluble aerosols are hydrophobic and do not act as CCN. We only calculate the growth of the soluble aerosols in this case. The equilibrium vapour pressure over the ammonium sulfate solution can be derived from Eqs. (2) and (3); and the kinetic growth of the droplet can be calculated based on Eq. (1). Figure 3 shows the calculated and measured $\mathrm{CCN}$ concentrations for various mass fraction of ammonium sulfate assuming the aerosols are external mixture. The ratio of the calculated to the measured $\mathrm{CCN}$ concentration is also shown in Table 1b. It is seen that the best-fit mass fraction of ammonium sulfate is $0.4,0.5,0.7,0.7$ and 0.6 at supersaturations of $0.056 \%, 0.083 \%, 0.17 \%, 0.35 \%$ and $0.70 \%$, respectively, for external mixing state.

It should be noted that external mixing state can generally lead to a better $\mathrm{CCN}$ closure than the internal mixing state for a certain mass fraction of soluble material in this study. The results indicate that the assumption of an internal mixture of $20-50 \%$ ammonium sulfate and some insoluble 
Table 1. Ratio of calculated to observed $\mathrm{CCN}$ number concentration on average at five supersaturations $(S)$ for different ammonium sulfate mass fraction $(\varepsilon)$ and mixing state. For each setup of the composition, we also calculated the averaged $\mathrm{CCN}_{\mathrm{cal}} / \mathrm{CCN}_{\mathrm{obs}}$ over all the supersaturations. The kinetic model is used and the mass accommodation coefficient of water is 0.04 .

\begin{tabular}{|c|c|c|c|c|c|c|c|c|c|c|}
\hline \multicolumn{11}{|l|}{ (a) } \\
\hline \multicolumn{11}{|c|}{ Internal mixture } \\
\hline$S(\%) / \epsilon$ & 1.0 & 0.9 & 0.8 & 0.7 & 0.6 & 0.5 & 0.4 & 0.3 & 0.2 & 0.1 \\
\hline 0.056 & 2.36 & 2.22 & 2.09 & 1.96 & 1.84 & 1.60 & 1.38 & 1.09 & 0.83 & 0.44 \\
\hline 0.083 & 1.96 & 1.86 & 1.75 & 1.65 & 1.46 & 1.36 & 1.19 & 0.95 & 0.75 & 0.37 \\
\hline 0.17 & 1.37 & 1.30 & 1.24 & 1.18 & 1.13 & 1.01 & 0.91 & 0.81 & 0.62 & 0.39 \\
\hline 0.35 & 1.41 & 1.37 & 1.32 & 1.28 & 1.24 & 1.15 & 1.07 & 0.99 & 0.83 & 0.62 \\
\hline 0.70 & 1.52 & 1.49 & 1.46 & 1.43 & 1.40 & 1.34 & 1.28 & 1.21 & 1.08 & 0.88 \\
\hline Ave & 1.72 & 1.65 & 1.57 & 1.50 & 1.42 & 1.30 & 1.16 & 1.01 & 0.82 & 0.54 \\
\hline
\end{tabular}

(b)

\begin{tabular}{lllllllllll}
\hline \multicolumn{10}{c}{ External mixture } \\
\hline$S(\%) / \epsilon$ & 1.0 & 0.9 & 0.8 & 0.7 & 0.6 & 0.5 & 0.4 & 0.3 & 0.2 & 0.1 \\
\hline 0.056 & 2.36 & 2.15 & 1.93 & 1.71 & 1.48 & 1.25 & 1.01 & 0.77 & 0.52 & 0.26 \\
0.083 & 1.96 & 1.79 & 1.61 & 1.42 & 1.23 & 1.04 & 0.84 & 0.64 & 0.43 & 0.22 \\
0.17 & 1.37 & 1.25 & 1.12 & 0.99 & 0.86 & 0.72 & 0.59 & 0.45 & 0.30 & 0.15 \\
0.35 & 1.41 & 1.28 & 1.16 & 1.02 & 0.89 & 0.75 & 0.60 & 0.46 & 0.31 & 0.16 \\
0.70 & 1.52 & 1.39 & 1.25 & 1.10 & 0.96 & 0.81 & 0.65 & 0.50 & 0.34 & 0.17 \\
\hline Ave & 1.72 & 1.57 & 1.41 & 1.25 & 1.08 & 0.91 & 0.74 & 0.56 & 0.38 & 0.19 \\
\hline
\end{tabular}

material for aerosols or the assumption of an external mixture of 40-70\% ammonium sulfate and some insoluble material for aerosols can generally lead to a good agreement between the calculated and observed CCN concentration in the experimental area. Actually the aerosol composition and mixing state are very complex. Ma et al. (2011) suggested that both internal and external mixing states exist at Wuqing, the experimental site in North China Plain. In general, aerosol composition and mixing state are both time-dependent and size-dependent. Our purpose is to provide a simple parameterization method for $\mathrm{CCN}$ prediction that may be used in a large scale model for the area.

In summary, solubility and mixing state each plays an important role under certain conditions at Wuqing in the experimental period. For example, $\mathrm{CCN}$ closure is more sensitive to solubility for external mixture, and for internal mixture with soluble mass fraction smaller than 0.4; but less sensitive to solubility for internal mixture when soluble mass fraction is larger than 0.4 (Figs. 2-3 and Table 1). CCN closure is sensitive to mixing state only when the soluble mass fraction is small (Figs. 2-3 and Table 1). This means that if aerosols contain large amount of soluble materials, mixing state is not important for predicting $\mathrm{CCN}$ number concentration, although external mixing state would lead to a slightly less predicted $\mathrm{CCN}$ than internal mixing state for a fixed soluble mass fraction.
It should be noted that this study assumes uniform composition for the entire aerosol size distribution and the experimental period. However, the aerosol soluble mass fraction may be different at different sizes and at different times in reality. We, therefore, investigated the aerosol number size distributions for cases that are above, nearly on, and below the 1:1 line in Fig. 1 to see if the three categories have different size modes (and hence possibly different composition). Results show that cases above the 1:1 line usually have smaller aerosol sizes and higher number concentrations, while cases on the 1:1 line and below the 1:1 line usually have larger aerosol sizes and lower number concentrations. The differences in the shape of the size distribution as well as the integral number concentration imply that aerosols in different categories can possibly have different sources or processes. An extensive analysis of the size distribution data and investigation of this result is beyond the scope of the present manuscript and will be the focus of a future study.

\subsection{Kinetic effect}

Previous studies often used the equilibrium model to calculate CCN number concentration (Broekhuizen et al., 2006; Jurányi et al., 2010; Wang et al., 2010). However, kinetic limitation is an important factor affecting droplet nucleation process and the equilibrium model can sometimes lead to a discrepancy in the calculated and observed droplet numbers (Nenes et al., 2001). Here, we compare the calculated 


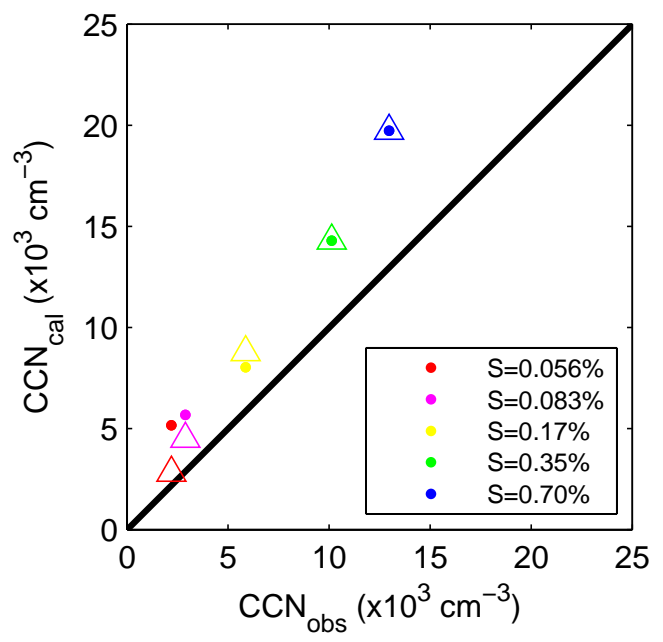

Fig. 4. Comparison between the average calculated CCN number concentration using the kinetic model (dot) and that using the equilibrium model (triangle). Different colours represent different supersaturations as before.

$\mathrm{CCN}$ number concentrations from the kinetic condensational growth model and the equilibrium model. As discussed in Sect. 3, the kinetic model considers a particle as CCN if its radius is larger than $0.5 \mu \mathrm{m}$ after the resident time $(10 \mathrm{~s})$, while in the equilibrium model a particle is considered as $\mathrm{CCN}$ if its critical supersaturation is smaller than the ambient supersaturation. The composition of dry aerosols is considered as pure ammonium sulfate in both models. The water accommodation coefficient is first set to be 0.04 on the basis of the laboratory study of Shaw and Lamb (1999). A sensitivity study on the water accommodation coefficient is also performed.

Figure 4 shows the averaged CCN number concentrations calculated from the kinetic and equilibrium models for various supersaturations. Both the observed and calculated CCN are averaged over the experimental time period for each supersaturation. Results for the kinetic model in Fig. 4 are the same as in Fig. 1. It is seen that CCN number concentration calculated with the kinetic model is $84 \%$ and $26 \%$ higher than that by the equilibrium model at supersaturations of $0.056 \%$ and $0.083 \%$, respectively, while it is $9 \%$ lower than that by the equilibrium model at a supersaturation of $0.17 \%$. Both models calculate the same CCN number concentration at supersaturations of $0.35 \%$ and $0.70 \%$. The reasons for this behaviour will be discussed below.

Figure 5 shows the growth curves of various bins at different supersaturations. Four bins are selected for each supersaturation: the smallest bin (bin 1), the largest bin (bin 110), and two intermediate bins including the smallest bin that can be considered as $\mathrm{CCN}$ in the kinetic model, and the smallest bin that can be considered as $\mathrm{CCN}$ in the equilibrium model. It can be seen that there are three types of growth characteristic for the intermediate bins. (1) Particles cannot
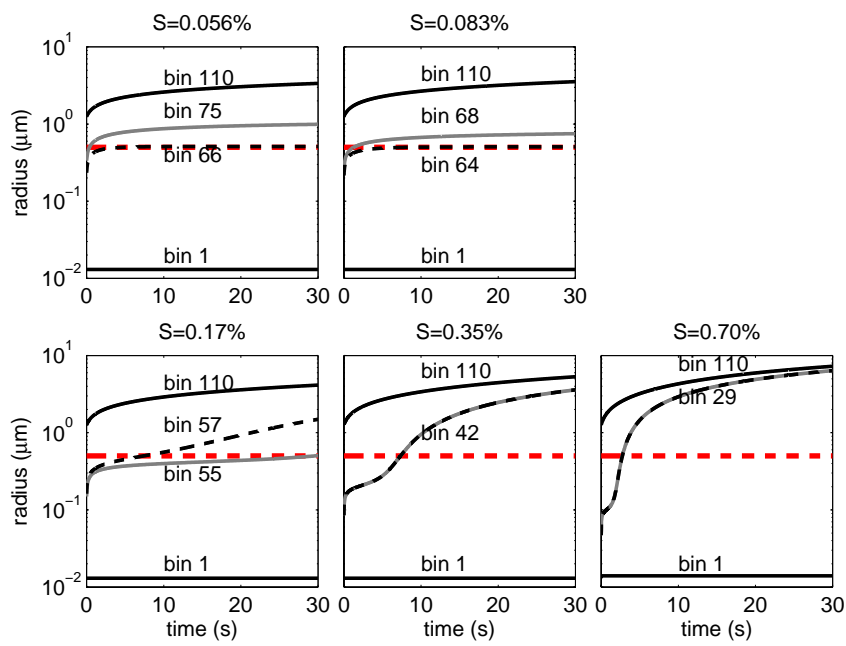

Fig. 5. Growth curves of four selected bins at each supersaturation $(S)$ : the smallest bin of aerosols (bin 1), the largest bin of aerosols (bin 110), the smallest bin of aerosols that can be considered as $\mathrm{CCN}$ based on the kinetic model (dashed black lines; bin 66 at $S=0.056 \%$, bin 64 at $S=0.083 \%$, bin 57 at $S=0.17 \%$, bin 42 at $S=0.35 \%$, bin 29 at $S=0.70 \%$ ) and the smallest bin of aerosols that can be considered as $\mathrm{CCN}$ based on the equilibrium model (solid gray lines: bin 75 for $S=0.056 \%$, bin 68 for $S=0.083 \%$, bin 55 for $0.17 \%$, bin 42 for $S=0.35 \%$, bin 29 for $S=0.70 \%$ ). A particle is considered as CCN if its radius is larger than $0.5 \mu \mathrm{m}$ (red dashed line) at $10 \mathrm{~s}$ using the kinetic model. The initial radii of selected bins and the time for these bins to grow to a detectable size can be seen in Table 2. The composition of aerosols is pure ammonium sulfate and the water accommodation coefficient is 0.04 .

be activated in the equilibrium model, but can still be considered as CCN based on the kinetic model, because their radii are larger than $0.5 \mu \mathrm{m}$ at $t=10 \mathrm{~s}$ (e.g., bin 66 at a supersaturation of $0.056 \%$, bin 64 at a supersaturation of $0.083 \%$ ). Therefore, the kinetic model calculates higher $\mathrm{CCN}$ number concentration than the equilibrium model at supersaturations of $0.056 \%$ and $0.083 \%$ for this study. (2) Particles can be activated in the equilibrium model, but cannot be considered as $\mathrm{CCN}$ in the kinetic model, because their radii are smaller than $0.5 \mu \mathrm{m}$ at $t=10 \mathrm{~s}$ (e.g., bin 55 at a supersaturation of $0.17 \%$ ). In this case, the kinetic model calculates lower CCN number concentration than the equilibrium model. (3) The smallest bin that can be considered as CCN based on the equilibrium model is consistent with that predicted by the kinetic model (e.g., bins 42 and 29 for the supersaturations of $0.35 \%$ and $0.70 \%$, respectively, in this study), leading to the same calculated CCN number concentration.

Analysis above indicates that the detectable radius of $\mathrm{CCN}$ counter and the resident time of aerosols in the column are very important parameters in the kinetic model. We define $r_{\mathrm{k}}$ as the smallest aerosol radius that can grow larger than the detectable radius after the resident time in the counter based on the kinetic model, and $r_{\mathrm{e}}$ as the smallest activated aerosol 

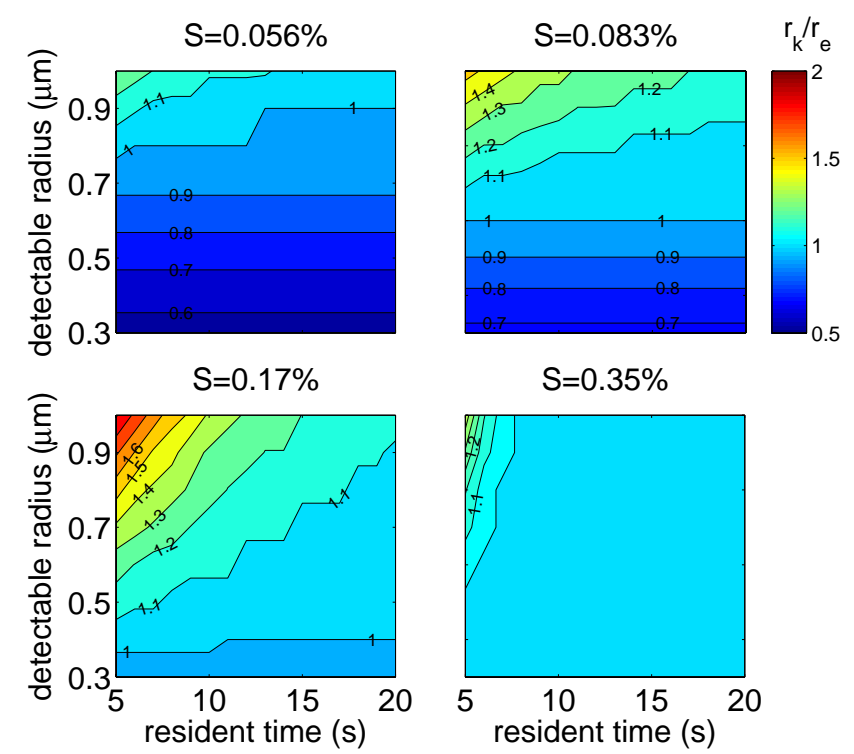

Fig. 6. Variation of $r_{\mathrm{k}} / r_{\mathrm{e}}$ at different resident times and detectable radii for different supersaturations. $r_{\mathrm{k}}$ represents the smallest aerosol radius that can grow larger than the detectable radius after the resident time in the counter based on the kinetic model, while $r_{\mathrm{e}}$ represents the smallest activated radius calculated with the equilibrium model. The isopleths are stepped because the detectable radius varies from 0.3 to $1.0 \mu \mathrm{m}$ with an interval of $0.1 \mu \mathrm{m}$, and the resident time varies from 5 to $20 \mathrm{~s}$ with interval of $1 \mathrm{~s}$. In addition, the aerosol size distribution is represented with discrete bins.

radius based on the equilibrium model. Figure 6 shows the ratio of $r_{\mathrm{k}}$ to $r_{\mathrm{e}}$ at different resident times (5-20 s) and different detectable radii $(0.3-1.0 \mu \mathrm{m})$ for various supersaturations. The composition of aerosols is assumed as pure ammonium sulfate and the water accommodation coefficient is 0.04 . It should be noted that $r_{\mathrm{k}}$ is smaller than $r_{\mathrm{e}}$ only at lower supersaturations ( $S=0.056$ and $0.083 \%$ ), indicating that the kinetic model will predict higher $\mathrm{CCN}$ number concentration than the equilibrium model because some "unactivated" particles are large enough to be considered as $\mathrm{CCN}$. This suggests that if a $\mathrm{CCN}$ counter has small detectable radius, very low supersaturations should be avoided for $\mathrm{CCN}$ measurements. It is also seen in Fig. 6 that if the resident time is small (e.g., $7 \mathrm{~s}$ and smaller) and the detectable radius is large (e.g., $0.8 \mu \mathrm{m}$ and larger), $r_{\mathrm{k}}$ is larger than $r_{\mathrm{e}}$ in this study, indicating that the CCN number concentration calculated with the kinetic model will be lower than that from the equilibrium model due to the kinetic limitation. In general, if particles stay in the column long enough, the kinetic limitation will have a small effect on $\mathrm{CCN}$ prediction. At supersaturations of $0.35 \%$ and higher $(0.70 \%)$, both resident time and detectable radius have a small impact on $\mathrm{CCN}$ prediction using the kinetic model.

The mass accommodation coefficient of water has been widely studied. A value of 1.0 has been used by Mozurkewich et al. (1986). However, results showed that the
Table 2. The time for various bins to grow larger than $0.5 \mu \mathrm{m}$ to be detected at different supersaturations. Water accommodation coefficient $\alpha=0.04,0.3$ and 1.0.

\begin{tabular}{llrrr}
\hline $\begin{array}{l}\text { Supersaturation } \\
(\%)\end{array}$ & $\begin{array}{l}\text { Initial Radius } \\
(\mathrm{nm})\end{array}$ & $\alpha=0.04$ & $\alpha=0.3$ & $\alpha=1.0$ \\
\hline 0.056 & 103 & $0.40 \mathrm{~s}$ & $0.20 \mathrm{~s}$ & $0.17 \mathrm{~s}$ \\
0.083 & 80 & $1.3 \mathrm{~s}$ & $0.62 \mathrm{~s}$ & $0.54 \mathrm{~s}$ \\
0.17 & 50 & $30 \mathrm{~s}$ & $14 \mathrm{~s}$ & $12 \mathrm{~s}$ \\
0.35 & 31 & $7.3 \mathrm{~s}$ & $3.0 \mathrm{~s}$ & $2.5 \mathrm{~s}$ \\
0.70 & 20 & $2.7 \mathrm{~s}$ & $1.0 \mathrm{~s}$ & $0.83 \mathrm{~s}$ \\
\hline
\end{tabular}

water accommodation coefficient is only 0.04 on the basis of the laboratory studies of Shaw and Lamb (1999). Recent studies have shown that the mass accommodation coefficient is larger than 0.3 in a flow chamber (Voigtländer et al., 2007). To investigate the sensitivity to the water accommodation coefficient $(\alpha)$, the simulations presented above $(\alpha=0.04)$ were repeated with $\alpha=0.3$ and $\alpha=1.0$. We focus on the smallest activated bin at each supersaturation based on the equilibrium model. The time for these particles to grow larger than $0.5 \mu \mathrm{m}$ radius for different $\alpha(0.04,0.3$ and 1.0$)$ is shown in Table 2. It can be seen that less time is needed if the water accommodation coefficient is higher. However, analysis indicates that if $\alpha$ is larger than 0.3 , the value of $\alpha$ has little influence on droplet growth and, hence, CCN number concentration prediction, while $\alpha$ as small as 0.04 has significant influence on droplet growth and the calculated CCN concentration due to the kinetic limitation.

It should be noted that although particles detected by the $\mathrm{CCN}$ counter at a given supersaturation are considered as $\mathrm{CCN}$, they may not be actually activated in the classical way. Figure 7 shows the time when a particle (pure ammonium sulfate) with certain initial dry radius can grow to its critical radius at a given supersaturation in the $\mathrm{CCN}$ counter. It can be seen that the time decreases as the supersaturation increases: it is longer than $100 \mathrm{~s}$ at a supersaturation of $0.056 \%$, while only on the order of seconds at a supersaturation of $0.70 \%$. It is also relatively larger at both the small-size end and the large-size end. A particle with a large dry radius and at a low critical supersaturation especially needs a long time to reach its critical radius because the linear growth rate is inversely proportional to droplet size. This kinetic mechanism that limits the formation of activated droplets is described by Chuang et al. (1997). At the small-size end, a particle also needs a longer time to reach its critical radius because the driving force (vapour difference between the ambient and the particle surface) for droplet growth becomes smaller as the particle grows closer to its critical radius. The result suggests that many droplets would not have sufficient time to grow to their critical radii in the $\mathrm{CCN}$ counter. However, the $\mathrm{CCN}$ counter cannot distinguish whether the droplets are really activated as $\mathrm{CCN}$, but can 


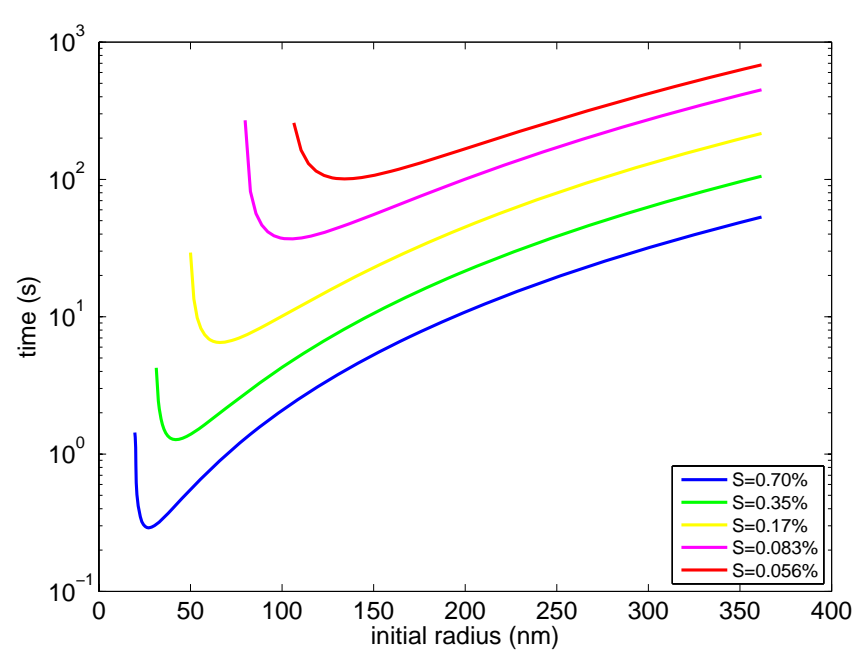

Fig. 7. The time required for particles to grow to their critical radii at different supersaturations. The $\mathrm{x}$-coordinate is the initial dry radii of aerosols, the composition of aerosols is ammonium sulfate and different colours represent different supersaturations. Water accommodation coefficient is 0.04 .

only detect droplets with radii larger than its detectable radius and count them as CCN.

It is generally seen that the sensitivity of $\mathrm{CCN}$ closure to kinetic effect is very complex and depends on supersaturation, resident time, detectable radius and mass accommodation coefficient. At higher supersaturation $(0.35 \%$ and $0.7 \%$ in this study), kinetic effect has little influence on CCN closure; at lower supersaturation $(0.056 \%, 0.083 \%$ and $0.17 \%$ in this study), kinetic effect can influence $\mathrm{CCN}$ closure in several ways: (a) if the detectable radius is small $(<0.5 \mu \mathrm{m})$, some "unactivated" particles may be large enough to be counted as CCN. A kinetic growth model can then predict more realistic and higher concentration of $\mathrm{CCN}$ than the equilibrium model in this case. (b) if the detectable radius is large $(>0.5 \mu \mathrm{m})$, and the resident time is shorter $(<10-30 \mathrm{~s})$, some particles may not have time to grow large enough to be counted as CCN due to kinetic limitation. Therefore, the kinetic growth model should be used to predict CCN concentration under this condition. (c) if the detectable radius is large $(>0.5 \mu \mathrm{m})$, and the resident time is longer $(>30 \mathrm{~s})$, kinetic limitation does not influence $\mathrm{CCN}$ closure. Both the kinetic growth model and equilibrium model can be used to predict $\mathrm{CCN}$ concentration. In addition, $\mathrm{CCN}$ closure is sensitive to mass accommodation coefficient if it is very small $(<0.1)$. On the opposite, if the mass accommodation coefficient is larger than 0.1 , it has little influence on $\mathrm{CCN}$ closure.

\section{Conclusions}

This study focuses on the CCN closure at Wuqing, a site in the North China Plain where high aerosols number concentrations existed, from 31 December 2009 to 20 Jan- uary 2010. The input initial dry aerosols to the kinetic condensational growth model and equilibrium model were observed by SMPS. The CCN concentrations were observed by a CCN counter. The kinetic model overpredicts the CCN concentrations by $40-140 \%$ in comparison with the observations for the supersaturation range in this study if assuming the aerosols are pure ammonium sulfate. Sensitivity of CCN closure to the aerosol mass fraction of soluble material and mixing state were investigated. Two extreme mixing states of aerosols were considered, including internally-mixed ammonium sulfate and insoluble material, and externally-mixed ammonium sulfate and insoluble material. Increasing the insoluble matters in the aerosols can decrease the calculated $\mathrm{CCN}$ number concentration and, thus, make the calculated $\mathrm{CCN}$ number concentration closer to the observed. It is found that external mixing state can lead to even less calculated $\mathrm{CCN}$ number concentration than the internal mixing state for a certain mass fraction of soluble material. Reasonable agreement of calculated CCN number concentrations with observed ones is obtained when we assume 0.2-0.5 mass fraction of ammonium sulfate internally mixed with insoluble material or 0.4-0.7 mass fraction of ammonium sulfate externally mixed with insoluble material in aerosols. It also should be noted that the results are valid for the winter season in the Wuqing area, while results in other seasons may be different because of different aerosol sources, meteorology and atmospheric chemistry processing.

CCN number concentrations calculated with the kinetic model and the equilibrium model were compared in this study. A particle is considered as $\mathrm{CCN}$ if its radius is larger than $0.5 \mu \mathrm{m}$ after resident time $(10 \mathrm{~s})$ in the kinetic model, while a particle is considered as $\mathrm{CCN}$ if its critical supersaturation is smaller than the ambient supersaturation in the equilibrium model. The $\mathrm{CCN}$ number concentration calculated with the kinetic model is higher than that by equilibrium model at the supersaturations of $0.056 \%$ and $0.083 \%$, because particles that are not activated at these supersaturations can grow larger than $0.5 \mu \mathrm{m}$ at $10 \mathrm{~s}$. However, the $\mathrm{CCN}$ number concentration calculated with the kinetic model is lower than that with the equilibrium model at a supersaturation of $0.17 \%$, because particles that can be activated based on the classical equilibrium theory cannot grow larger than $0.5 \mu \mathrm{m}$ at $10 \mathrm{~s}$ due to kinetic limitation, hence, are not counted as $\mathrm{CCN}$ in the kinetic model. Analysis indicates that the detectable radius of $\mathrm{CCN}$ counter and the resident time of particles in the column can affect the calculated CCN number concentration at lower supersaturations based on the kinetic model. If a $\mathrm{CCN}$ counter has small detectable radius, very low supersaturations should be avoided for $\mathrm{CCN}$ measurements. If the resident time of particles in the $\mathrm{CCN}$ counter is short, kinetic limitation on droplet growth must be considered. Generally if particles stay in the column long enough, the kinetic limitation will have small effect on CCN prediction. At higher supersaturations, both resident time and detectable radius have small impact on $\mathrm{CCN}$ prediction using 
the kinetic simulation. The influence of the water accommodation coefficient on droplet growth was also investigated. Larger water accommodation coefficient $(\alpha>0.3)$ does not significantly limit droplet growth but smaller $\alpha(0.04)$ has great influence on droplet growth.

Acknowledgements. This work is supported by the National 973 Project of China (2011CB403402), the National Natural Science Foundation of China (NSFC) under grants 40875001, 40975059 and 41075097, and the Chinese National Public Benefit Research Foundation of Meteorology (Grant GYHY201006011).

Edited by: D. Covert

\section{References}

Ackerman, A. S., Toon, O. B., Stevens, D. E., Heymsfield, A. J., Ramanathan, V., and Welton, E. J.: Reduction of tropical cloudiness by soot, Science, 288, 1042-1047, 2000.

Ackerman, A. S., Kirkpatrick, M. P., Stevens, D. E., and Toon, O. B.: The impact of humidity above stratiform clouds on indirect climate forcing, Nature, 432, 1014-1017, 2004.

Albrecht, B. A.: Aerosols, cloud microphysics, and fractional cloudness, Science, 245, 1227-1230, 1989.

Anderson, T. L., Charlson, R. J., Schwartz, S. E., Knutti, R., Boucher, O., Rodhe, H., and Heintzenberg, J.: Climate forcing by Aerosols - a hazy picture, Science, 300, 1103-1104, 2003.

Andreae, M. O. and Rosenfeld, D.: Aerosol-cloud-precipitation interactions. Part 1. The nature and sources of cloud-active aerosols, Earth Sci. Rev., 89, 13-41, 2008.

Bates, T. S., Huebert, B. J., Gras, J. L., Griffiths, F. B., and Durkee, P. A.: International Global Atmospheric Chemistry (IGAC) Project's First Aerosol Characterization Experiment (ACE 1): Overview, J. Geophys. Res., 103, 16297-16318, 1998.

Barth, M. C., Rasch, P. J., Kiehl, J. T., Benkovitz, C. M., and Schwartz, S. E.: Sulfur chemistry in the NCAR CCM: Description, evaluation, features and sensitivity to aqueous chemistry, J. Geophys. Res., 106, 20311-20322, 2000.

Bigg, E. K.: Discrepancy between observation and prediction of concentrations of cloud condensation nuclei, Atmos. Res., 20, 81-86, 1986.

Bilde, M. and Svenningsson, B.: CCN activation of slightly soluble organics: the importance of small amounts of inorganic salt and particle phase, Tellus, 56B, 128-134, 2004.

Boucher, O. and Anderson, T. L.: GCM assessment of the sensitivity of direct climate forcing by anthropogenic sulfate aerosols to aerosol size and chemistry, J. Geophys. Res., 100, 26117-26134, 1995.

Boucher, O. and Lohmann, U.: The sulfate-CCN-cloud albedo effect: A sensitivity study with two general circulation models, Tellus B, 47, 281-300, 1995.

Bougiatioti, A., Fountoukis, C., Kalivitis, N., Pandis, S. N., Nenes, A., and Mihalopoulos, N.: Cloud condensation nuclei measurements in the marine boundary layer of the Eastern Mediterranean: CCN closure and droplet growth kinetics, Atmos. Chem. Phys., 9, 7053-7066, doi:10.5194/acp-9-7053-2009, 2009.

Brenguier, J.-L., Pawlowska, H., Schüller, L., Preusker, R., Fischer, J., and Fouquart, Y.: Radiative properties of boundary layer clouds: Droplet effective radius versus number concentration, J. Atmos. Sci., 57, 803-821, 2000.

Broekhuizen, K., Kumar, P. P., and Abbatt, J. P. D.: Partially soluble organics as cloud condensation nuclei: Role of trace soluble and surface active species, Geophys. Res. Lett., 31, L01107, doi:10.1029/2003GL018203, 2004.

Broekhuizen, K., Chang, R.Y.-W., Leaitch, W. R., Li, S.-M., and Abbatt, J. P. D.: Closure between measured and modeled cloud condensation nuclei $(\mathrm{CCN})$ using size-resolved aerosol compositions in downtown Toronto, Atmos. Chem. Phys., 6, 2513-2524, doi:10.5194/acp-6-2513-2006, 2006.

Cantrell, W., Shaw, G., Cass, G. R., Chowdhury, Z., Hughes, L. S., Prather, K. A., Guazzotti, S. A., and Coffee, K. R.: Closure between aerosol particles and cloud condensation nuclei at Kaashidhoo Climate Observatory, J. Geophys. Res., 106, 2871128718, 2001.

Chin, M., Rood, R. B., Lin, S.-J., Muller, J. F., and Thompson, A. M.: Atmospheric sulfur cycle in the global model GOCART: Model description and global properties, J. Geophys. Res., 105, 24671-24687, 2000.

Chuang, P. Y., Charlson, R., and Seinfeld, J.: Kinetic limitation on droplet formation in clouds, Nature, 390, 594-596, 1997.

Conant, W. C., VanReken, T., Rissman, T., Varutbangkul, V., Jonsson, H., Nenes, A., Jimenez, J., Delia, A., Bahreini, R., Roberts, G., Flagan, R., and Seinfeld, J. H.: Aerosol-cloud drop concentration closure in warm clouds, J. Geophys. Res., 109, D13204, doi:10.1029/2003JD004324, 2004.

Davidovits, P., Worsnop, D. R., Jayne, J. T., Kolb, C. E.,Winkler, P., Vrtala, A., Wagner, P. E., Kulmala, M., Lehtinen, K. E. J., Vesala, T., and Mozurkewich, M.: Mass accommodation coefficient of water vapour on liquid water, Geophys. Res. Lett., 31, L22111, doi:10.1029/2004GL020835, 2004.

Delene, D. J. and Ogren, J. A.: Variability of aerosol optical properties at four North American surface monitoring sites, J. Atmos. Sci., 59, 1135-1150, 2002.

Deng, Z. Z., Zhao, C. S., Ma, N., Liu, P. F., Ran, L., Xu, W. Y., Chen, J., Liang, Z., Liang, S., Huang, M. Y., Ma, X. C., Zhang, Q., Quan, J. N., Yan, P., Henning, S., Mildenberger, K., Sommerhage, E., Schäfer, M., Stratmann, F., and Wiedensohler, A.: Size-resolved and bulk activation properties of aerosols in the North China Plain, Atmos. Chem. Phys., 11, 3835-3846, doi:10.5194/acp-11-3835-2011, 2011.

Dusek, U., Covert, D., Wiedensholer, A., Neususs, C., Weise, D., and Cantrell, W.: Cloud condensation nuclei spectra derived from size distributions and hygroscopic properties of the aerosol in coastal southwest Portugal during ACE-2, Tellus, 55B, 35-53, 2003.

Dusek, U., Reischl, G. P., and Hitzenberger, R.: CCN activation of pure and coated carbon black particles, Environ. Sci. Technol., 40, 1223-1230, 2006.

Ervens, B., Cubison, M., Andrews, B., Feingold, G., Ogren, J. A., Jimenez, J. L., and Nenes, A.: Prediction of CCN number concentration using measurements of aerosols size distributions and composition and light scattering enhancement due to humidity, J. Geoph. Res., 112, D10S32, doi:10.1029/2006JD007426, 2007.

Ervens, B., Cubison, M. J., Andrews, E., Feingold, G., Ogren, J. A., Jimenez, J. L., Quinn, P. K., Bates, T. S., Wang, J., Zhang, Q., Coe, H., Flynn, M., and Allan, J. D.: CCN predictions using simplified assumptions of organic aerosol composition and mixing 
state: a synthesis from six different locations, Atmos. Chem. Phys., 10, 4795-4807, doi:10.5194/acp-10-4795-2010, 2010.

Facchini, M. C., Mircea, M., Fuzzi, S., and Charlson, R. J.: Cloud albedo enhancement by surface-active organic solutes in growing droplets, Nature, 401, 257-259, 1999.

Feingold, G., Eberhard, W. L., Veron, D. E., and Previdi, M.: First measurements of the Twomey indirect effect using ground-based remote sensors, Geophys. Res. Lett., 30, 1287, doi:10.1029/2002GL016633, 2003.

Ferek, R. J., Hegg, D. A., Hobbs, P. V., Durkee, P., and Nielsen, K.: Measurements of ship-induced tracks in clouds off the Washington coast, J. Geophys. Res., 103, 23199-23206, 1998.

Ferek, R. J., Garret, T., Hobbs, P. V., Strader, S., Johnson, D., Taylor, J. P., Nielsen, K., Ackerman, A. S., Kogan, Y., Liu, Q., Albrecht, B. A., and Babb, D.: Drizzle suppression in ship tracks, J. Atmos. Sci., 57, 2707-2728, 2000.

Henning, S., Rosenørn, T., D’Anna, B., Gola, A. A., Svenningsson, B., and Bilde, M.: Cloud droplet activation and surface tension of mixtures of slightly soluble organics and inorganic salt, Atmos. Chem. Phys., 5, 575-582, doi:10.5194/acp-5-575-2005, 2005.

Heymsfield, A. J. and MacFarquhar, G. M., Microphysics of INDOEX clean and polluted trade cumulus clouds, J. Geophys. Res.-Atmos., 106, 28653-28673, 2001.

Hudson, J. G. and Yum, S. S.: Maritime-continental drizzle contrasts in small cumuli, J. Atmos. Sci., 58, 915-926, 2001.

Intergovernmental panel on Climate Change (IPCC): Climate change 2007: The physical science basis, Cambridge University Press, New York, 2007.

Jurányi, Z., Gysel, M., Weingartner, E., DeCarlo, P. F., Kammermann, L., and Baltensperger, U.: Measured and modelled cloud condensation nuclei number concentration at the high alpine site Jungfraujoch, Atmos. Chem. Phys., 10, 7891-7906, doi:10.5194/acp-10-7891-2010, 2010.

Kanakidou, M., Seinfeld, J. H., Pandis, S. N., Barnes, I., Dentener, F. J., Facchini, M. C., Van Dingenen, R., Ervens, B., Nenes, A., Nielsen, C. J., Swietlicki, E., Putaud, J. P., Balkanski, Y., Fuzzi, S., Horth, J., Moortgat, G. K., Winterhalter, R., Myhre, C. E. L., Tsigaridis, K., Vignati, E., Stephanou, E. G., and Wilson, J.: Organic aerosol and global climate modelling: a review, Atmos. Chem. Phys., 5, 1053-1123, doi:10.5194/acp-5-1053-2005, 2005.

Kaufman, Y. J., Tanre, D., and Boucher, O.: A satellite view of aerosols in the climate system, Nature, 419, 215-223, doi:10.1038/nature01091, 2002.

Khvorostyanov, V. I. and Curry, J. A.: Refinements to the Köhler's theory of aerosol equilibrium radii, size spectra and droplet activation: Effects of humidity and insoluble fraction, J. Geophys. Res., 112, D05206, doi:10.1029/2006JD007672, 2007.

Koch, D., Jacob, D., Tegen, I., Rind, D., and Chin, M.: Tropospheric sulfur simulation and sulfate direct radiative forcing in the Goddard Institute for Space Studies general circulation model, J. Geophys. Res. A., 104, 23799-23822, 1999.

Koch, D., Balkanski, Y., Bauer, S. E., Easter, R. C., Ferrachat, S., Ghan, S. J., Hoose, C., Iversen, T., Kirkevåg, A., Kristjansson, J. E., Liu, X., Lohmann, U., Menon, S., Quaas, J., Schulz, M., Seland, Ø., Takemura, T., and Yan, N.: Soot microphysical effects on liquid clouds, a multi-model investigation, Atmos. Chem. Phys., 11, 1051-1064, doi:10.5194/acp-11-1051-2011, 2011.
Köhler, H.: The nucleus in and the growth of hygroscopic droplets, Trans. Farad. Soc., 32, 1152-1161, 1936.

Kulmala, M., Laaksonen, A., Charlson, R. J., and Korhonen, P.: Clouds without supersaturation, Nature, 388, 336-337, 1997.

Laaksonen, A., Korhonen, P., Kulmala, M., and Charlson, R. J.: Modification of the Köhler equation to include soluble trace gases and slightly soluble substances, J. Atmos. Sci., 55, 1859 1866, 1998.

Laaksonen, A., Vesala, T., Kulmala, M., Winkler, P. M., and Wagner, P. E.: Commentary on cloud modelling and the mass accommodation coefficient of water, Atmos. Chem. Phys., 5, 461-464, doi:10.5194/acp-5-461-2005, 2005.

Lance, S., Medina, J., Smith, J. N., and Nenes, A.: Mapping the operation of the dmt continuous flow CCN counter, Aerosol Sci. Tech., 40, 242-254, 2006.

Lathem, T. L. and Nenes, A.: Water vapour depletion in the DMT continuous-flow CCN chamber: Effects on supersaturation and droplet growth, Aerosol Sci. Tech., 45, 604-615, doi:10.1080/02786826.2010.551146, 2011.

Liu, P. F., Zhao, C. S., Göbel, T., Hallbauer, E., Nowak, A., Ran, L., Xu, W. Y., Deng, Z. Z., Ma, N., Mildenberger, K., Henning, S., Stratmann, F., and Wiedensohler, A.: Hygroscopic properties of aerosol particles at high relative humidity and their diurnal variations in the North China Plain, Atmos. Chem. Phys., 11, 3479-3494, doi:10.5194/acp-11-3479-2011, 2011.

Lohmann, U. and Feichter, J.: Impact of sulfate aerosols on albedo and lifetime of clouds: A sensitivity study with the ECHAM GCM, J. Geophys. Res., 102, 13685-13700, 1997.

Lohmann, U. and Feichter, J.: Global indirect aerosol effects: a review, Atmos. Chem. Phys., 5, 715-737, doi:10.5194/acp-5-7152005, 2005.

Ma, N., Zhao, C. S., Nowak, A., Müller, T., Pfeifer, S., Cheng, Y. F., Deng, Z.Z., Liu, P. F., Xu, W. Y., Ran, L., Yan, P., Göbel, T., Hallbauer, E., Mildenberger, K., Henning, S., Yu, J., Chen, L. L., Zhou, X. J., Stratmann, F., and Wiedensohler, A.: Aerosol optical properties in the North China Plain during HaChi campaign: an in-situ optical closure study, Atmos. Chem. Phys., 11, 59595973, doi:10.5194/acp-11-5959-2011, 2011.

Marek, R. and Straub, J.: Analysis of the evapouration coefficient and the condensation coefficient of water, Int. J. Heat Mass Transf., 44, 39-53, 2001.

McFiggans, G., Alfarra, M., Allan, J., Bower, K., Coe, H., Cubison, M., Topping, D., Williams, P., Decesari, S., Facchini, C., and Fuzzi, S.: Simplification of the representation of the organic component of atmospheric particulates, Faraday Discuss., 130, 341-362, 2005.

McFiggans, G., Artaxo, P., Baltensperger, U., Coe, H., Facchini, M. C., Feingold, G., Fuzzi, S., Gysel, M., Laaksonen, A., Lohmann, U., Mentel, T. F., Murphy, D. M., O’Dowd, C. D., Snider, J. R., and Weingartner, E.: The effect of physical and chemical aerosol properties on warm cloud droplet activation, Atmos. Chem. Phys., 6, 2593-2649, doi:10.5194/acp-6-2593-2006, 2006.

Mozurkewich, M.: Aerosol Growth and the Condensation Coefficient for Water - a Review, Aerosol Sci. Tech., 5, 223-236, 1986.

Murphy, D. M., Cziczo, D. J., Froyd, K. D., Hudson, P. K., Matthew, B. M., Middlebrook, A. M., Peltier, R. E., Sullivan, A., Thomson, D. S., and Weber, R. J.: Single-particle mass spectrometry of tropospheric aerosol particles, J. Geophys. Res., 111, D23S32, doi:10.1029/2006JD007340, 2006. 
Nenes, A., Ghan, S., Abdul-Razzak, H., Chuang, P. Y., and Seinfeld, J. H.: Kinetic limitations on cloud droplet formation and impact on cloud albedo, Tellus, 53B, 133-149, 2001.

Nenes, A., Charlson, R., Facchini, M., Kulmala, M., Laaksonen, A., and Seinfeld, J. H.: Can chemical effects on cloud droplet number rival the first indirect effect?, Geophys. Res. Lett., 29, 1848, doi:10.1029/2002GL015295, 2002.

Peng, Y. and Lohmann, U.: Sensitivity study of the spectral dispersion of the cloud droplet size distribution on the indirect aerosol effect, Geophys. Res. Lett., 30, 1507, doi:10.1029/2003GL017192, 2003.

Penner, J. E., Dong, X., and Chen, Y.: Observational evidence of a change in radiative forcing due to the indirect aerosol effect, Nature, 427, 231-234, 2004.

Petters, M. D. and Kreidenweis, S. M.: A single parameter representation of hygroscopic growth and cloud condensation nucleus activity, Atmos. Chem. Phys., 7, 1961-1971, doi:10.5194/acp-71961-2007, 2007.

Petters, M. D. and Kreidenweis, S. M.: A single parameter representation of hygroscopic growth and cloud condensation nucleus activity - Part 2: Including solubility, Atmos. Chem. Phys., 8, 6273-6279, doi:10.5194/acp-8-6273-2008, 2008.

Pruppacher, H. R. and Klett, J. D.: Microphysics of Clouds and Precipitation, 2nd Edn., Kluwer Academic Publishers, Dordrecht, 511 pp., 1997.

Quinn, P. K., Covert, D. S., Bates, T. S., Kapustin, V. N., RamseyBell, D. C., and Mclnnes, L. M.: Dimethylsulfide/cloud condensation nuclei/climate system: relevant size-resolved measurements of the chemical and physical properties of atmospheric aerosol particles, J. Geophys. Res., 98, 10411-10427, 1993.

Ramanathan, V., Crutzen, P. J., Lelievald, J., Mitra, A. P., Althausen, D., Anderson, J., Andreae, M. O., Cantrell, W., Cass, G. R., Chung, C. E., Clarke, A. D., Coakley, J. A., Collins, W. D., Conant, W. C., Dulac, F., Heintzenberg, J., Heymsfield, A. J., Holben, B., Howell, S., Hudson, J., Jayaraman, A., Kiehl, J. T., Krishnamurti, T. N., Lubin, D., MacFarquhar, G., Novakov, T., Ogren, J. A., Podgorny, I. A., Prather, K., Priestley, K., Prospero, J. M., Quinn, P. K., Rajeev, K., Rasch, P., Rupert, S., Sadourny, R., Satheesh, S. K., Shaw, G. E., Sheridan, P., and Valero, F. P. J.: Indian Ocean Experiment: An integrated analysis of the climate forcing and effects of the great Indo-Asian haze, J. Geophys. Res., 106, 28371-28398, 2001.

Raymond, T. M. and Pandis, S. N.: Cloud activation of singlecomponent organic aerosol particles, J. Geophys. Res., 107, 4787, doi:10.1029/2002JD002159, 2002.

Raymond, T. M. and Pandis, S. N.: Formation of cloud droplets by multicomponent organic particles, J. Geophys. Res., 108, 4469, doi:10.1029/2003JD003503, 2003.

Roberts, G. C. and Nenes, A.: A continuous-flow streamwise thermal-gradient $\mathrm{CCN}$ chamber for atmospheric measurements, Aerosol Sci. Tech., 39, 206-221, 2005.

Rose, D., Gunthe, S. S., Mikhailov, E., Frank, G. P., Dusek, U., Andreae, M. O., and Pöschl, U.: Calibration and measurement uncertainties of a continuous-flow cloud condensation nuclei counter (DMT-CCNC): CCN activation of ammonium sulfate and sodium chloride aerosol particles in theory and experiment, Atmos. Chem. Phys., 8, 1153-1179, doi:10.5194/acp-8-11532008, 2008.
Rosenfeld, D.: Suppression of rain and snow by urban and industrial air pollution, Science, 287, 1793-1796, 2000.

Rotstayn, L. D. and Liu, Y.: Sensitivity of the first indirect aerosol effect to an increase of cloud droplet spectral dispersion with droplet number concentration, J. Climate, 16, 3476-3481, 2003.

Ruehl, C. R., Chuang, P. Y., and Nenes, A.: How quickly do cloud droplets form on atmospheric particles?, Atmos. Chem. Phys., 8, 1043-1055, doi:10.5194/acp-8-1043-2008, 2008.

Schwartz, S. E., Harshvardhan, and Benkovitz, C. M.: Influence of anthropogenic aerosol on cloud optical depth and albedo shown by satellite measurements and chemical transport modeling, P. Natl. Acad. Sci., 99, 1784-1789, 2002.

Schwarz, J. P., Gao, R. S., Fahey, D. W., Thomson, D. S., Watts, L. A., Wilson, J. C., Reeves, J. M., Baumgardner, D. G., Kok, G. L., Chung, Schulz, S. M., Hendricks, J., Lauer, A., Kärcher, B., Slowik, J. G., Rosenlof, K. H., Thompson, T. L., Langford, A. O., Lowenstein, M., and Aikin, K. C.: Single-particle measurements of midlatitude black carbon and light-scattering aerosols from the boundary layer to the lower stratosphere, J. Geophys. Res., 111, D16207, doi:10.1029/2006JD007076, 2006.

Seinfeld, J. H. and Pandis, S. N.: Atmospheric Chemistry and Physics: From Air Pollution to Climate Change, John Wiley \& Sons, Inc., New York City, NY, 792 pp., 1998.

Shantz, N. C., Chang, R. Y.-W., Slowik, J. G., Vlasenko, A., Abbatt, J. P. D., and Leaitch, W. R.: Slower CCN growth kinetics of anthropogenic aerosol compared to biogenic aerosol observed at a rural site, Atmos. Chem. Phys., 10, 299-312, doi:10.5194/acp10-299-2010, 2010.

Shaw, R. A. and Lamb, D.: Experimental determination of the thermal accommodation and condensation coefficients of water, J. Chem. Phys., 111, 10659-10663, 1999.

Shulman, M. L., Jacobson, M. C., Carlson, R. J., Synovec, R. E., and Young, T. E.: Dissolution behaviour and surface tension effects of organic compounds in nucleation cloud droplets, Geophys. Res. Lett., 23, 277-280, 1996.

Stroud, C. A., Nenes, A., Jimenez, J. L., DeCarlo, P. F., Huffman, J. A., Bruintjes, R., Nemitz, E., Delia, A. E., Toohey, D. W., Guenther, A. B., and Nandi, S.: Cloud activating properties of aerosol observed during celtic, J. Atmos. Sci., 64, 441-459, 2007.

Svenningsson, B., Rissler, J., Swietlicki, E., Mircea, M., Bilde, M., Facchini, M. C., Decesari, S., Fuzzi, S., Zhou, J., Mønster, J., and Rosenørn, T.: Hygroscopic growth and critical supersaturations for mixed aerosol particles of inorganic and organic compounds of atmospheric relevance, Atmos. Chem. Phys., 6, 1937-1952, doi:10.5194/acp-6-1937-2006, 2006.

Tang, I. N. and Munkelwitz, H. R.: Water activities, densities, and refractive indices of aqueous sulfates and sodium nitrate droplets of atmospheric importance, J. Geophys. Res., 99, 801-808, 1994.

Textor, C., Schulz, M., Guibert, S., Kinne, S., Balkanski, Y., Bauer, S., Berntsen, T., Berglen, T., Boucher, O., Chin, M., Dentener, F., Diehl, T., Easter, R., Feichter, H., Fillmore, D., Ghan, S., Ginoux, P., Gong, S., Grini, A., Hendricks, J., Horowitz, L., Huang, P., Isaksen, I., Iversen, I., Kloster, S., Koch, D., Kirkevåg, A., Kristjansson, J. E., Krol, M., Lauer, A., Lamarque, J. F., Liu, X., Montanaro, V., Myhre, G., Penner, J., Pitari, G., Reddy, S., Seland, $\varnothing .$, Stier, P., Takemura, T., and Tie, X.: Analysis and quantification of the diversities of aerosol life cycles within AeroCom, Atmos. Chem. Phys., 6, 1777-1813, doi:10.5194/acp-6-1777-2006, 2006. 
Twomey, S.: The Influence of Pollution on Shortwave Albedo of Clouds, J. Atmos. Sci., 34, 1149-1152, 1977.

Väkevä, M., Kulmala, M., Stratmann, F., and Hämeri, K.: Field measurements of hygroscopic properties and state of mixing of nucleation mode particles, Atmos. Chem. Phys., 2, 55-66, doi:10.5194/acp-2-55-2002, 2002.

VanReken, T. M., Rissman, T. A., Roberts, G. C., Varutbangkul, V., Jonsson, H. H., Flagan, R. C., and Seinfeld, J. H.: Toward aerosol/cloud condensation nuclei $(\mathrm{CCN})$ closure during CRYSTAL-FACE, J. Geophys. Res., 108, 4633, doi:10.1029/2003JD003582, 2003.

Voigtländer, J., Stratmann, F., Niedermeier, D., Wex, H., and Kiselev, A.: Mass accomodation coefficient of water: A combined computational fluid dynamics and experimental analysis, J. Geophys. Res., 112, D20208, doi:10.1029/2007JD008604, 2007.

Wang, J., Cubison, M. J., Aiken, A. C., Jimenez, J. L., and Collins, D. R.: The importance of aerosol mixing state and size-resolved composition on $\mathrm{CCN}$ concentration and the variation of the importance with atmospheric aging of aerosols, Atmos. Chem. Phys., 10, 7267-7283, doi:10.5194/acp-10-7267-2010, 2010.

Wang, Y., Zhuang, G., Sun Y., and An, Z.: The variation of characteristics and formation mechanisms of aerosols in dust, haze, and clear days in Beijing, Atmos. Environ., 40, 6579-6591, 2006.

Ward, D. S., Eidhammer, T., Cotton, W. R., and Kreidenweis, S. M.: The role of the particle size distribution in assessing aerosol composition effects on simulated droplet activation, Atmos. Chem. Phys., 10, 5435-5447, doi:10.5194/acp-10-5435-2010, 2010.
Wu, Z., Hua, M., Lin, P., Liu, S., Wehner, B., and Wiedensohler, A.: Particle number size distribution in the urban atmosphere of Beijing, China, Atmos. Environ., 42, 7967-7980, 2008.

Xu, W. Y., Zhao, C. S., Ran, L., Deng, Z. Z., Liu, P. F., Ma, N., Lin, W. L., Xu, X. B., Yan, P., He, X., Yu, J., Liang, W. D., and Chen, L. L.: Characteristics of pollutants and their correlation to meteorological conditions at a suburban site in the North China Plain, Atmos. Chem. Phys., 11, 4353-4369, doi:10.5194/acp-114353-2011, 2011.

Xue, H. W. and Feingold, G.: Large-eddy simulations of trade wind cumuli: Investigation of aerosol indirect effects, J. Atmos. Sci., 63, 1605-1622, 2006.

Zhang, Q., Jimenez, J. L., Canagaratna, M. R., Allan, J. D., Coe, H., Ulbrich, I., Alfarra, M. R., Takami, A., Middlebrook, A. M., Sun, Y. L., Dzepina, K., Dunlea, E., Docherty, K., DeCarlo, P. F., Salcedo, D., Onasch, T., Jayne, J. T., Miyoshi, T., Shimono, A., Hatakeyama, S., Takegawa, N., Kondo, Y., Schneider, J., Drewnick, F., Weimer, S., Demerjian, K., Williams, P., Bower, K., Bahreini, R., Cottrell, L., Griffin, R. J., Rautiainen, J., Sun, J. Y., Zhang, Y. M., and Worsnop, D. R.:: Ubiquity and dominance of oxygenated species in organic aerosols in anthropogenicallyinfluenced Northern Hemisphere midlatitudes, Geophys. Res. Lett., 34, L13801, doi:10.1029/2007GL029979, 2007. 